\title{
Morphological priming effects on children's spelling
}

\author{
Joao Manuel Rosa $\cdot$ Terezinha Nunes
}

Published online: 30 October 2007

(C) Springer Science+Business Media B.V. 2007

\begin{abstract}
Previous research has suggested that children in the early grades of primary school do not have much awareness of morphemes. In this study, a priming paradigm was used to try to detect early signs of morphological representation of stems through a spelling task presented to Portuguese children $(N=805$; age range 6-9 years). Primes shared the stem with the targets and contained well-articulated, stressed vowels; the stems of the target words and pseudo-words contained nonstressed schwa vowels, which typically result in spelling difficulties. If priming proved effective, the well-articulated vowels in the prime should result in an improvement in the spelling of the schwa vowels. Primes were presented in two conditions: in only-oral or in oral-plus-written form. Effectiveness of priming was assessed by comparison with a no-priming condition. For both words and pseudowords, there was a significant interaction between priming effects and grade. No priming effects were detected in 6- and 7-year-old children; oral-plus-written priming produced higher rates of correct vowel spelling for 8- and 9-year-olds; only-oral priming was effective in improving the vowel spelling of 9-year-olds. Thus older children can use morphological information under priming conditions when the prime and the target are not phonologically transparent but there is no evidence to suggest that younger children do so.
\end{abstract}

Keywords Morphology $\cdot$ Morphological priming $\cdot$ Spelling $\cdot$ Spelling of stems

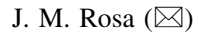

Instituto Politecnico de Lisboa, Escola Superior de Educacao, Campus de Benfica do IPL, Lisboa 1549-003, Portugal

e-mail: jmsrosa@hotmail.com

T. Nunes

Department of Educational Studies, University of Oxford, 15 Norham Gardens, Oxford OX2 6PY, UK
} 


\section{Introduction}

This study aims to investigate whether it is possible to improve children's spelling of schwa vowels through the use of morphological primes-thus activating their implicit knowledge of morphology. The study was carried out in European Portuguese, whose orthography is generally transparent. However, when a suffix is added to a base form, there is often a shift in stress and a clearly pronounced vowel in the base form becomes a schwa vowel in the derived form [e.g., "tambor" (drum) has a well articulated vowel, represented by the letter "o", but "tamborilar" (to drum) has a schwa vowel in the same position, closer to the semivowel /w/]. Portuguese primary school children often misspell the vowels in the derived form in these cases because these vowels are not predictable from the pronunciation. This study investigated whether it is possible to improve children's spelling of derived words containing a schwa vowel through priming techniques. If priming proves effective in improving the spelling of a vowel that cannot be identified through phonology, it will be concluded that children can use implicit knowledge to represent morphology in spelling. So far as we know, this is the first time that this method is used in the study of children's spelling processes.

It is generally accepted that priming works at the level of implicit knowledge because priming paradigms involve on-line tasks (i.e., tasks in which participants speak, read or write), and representation of linguistic sub-lexical units in on-line tasks has to be processed too quickly for people to be aware of the nature of the representations they are using (Karmiloff-Smith, 1992). Evidence from word recognition (Kempley \& Morton, 1982) and lexical decision experiments (Emmorey, 1989; Forster \& Azuma, 2000; Laudanna, Badecker, \& Caramazza, 1989, 1992; Laudanna, Cermele, \& Caramazza, 1997; Raveh \& Rueckl, 2000) with adults suggests that the ability to recognise a target word is facilitated by a prime that shares its stem. A prime (e.g., harm) that contains the same stem as a target (harmless) speeds the recognition of the target word, whereas it inhibits the recognition of a phonologically related but morphologically unrelated target (harmony). This evidence suggests that words are represented in the mental lexicon not only as whole words but also analysed in morphemes. These studies further demonstrated that priming effects can also be observed with pseudowords in lexical decision tasks (Caramazza, Laudanna, \& Romani, 1988). This suggests that the representation of morphemes must not be viewed simply as entries in the mental lexicon: adults must be parsing pseudowords according to a morphemic structure at some stage when they are making lexical decisions about these items (Chialant \& Caramazza, 1995). It thus becomes an important question to examine when the process of analysing words into morphemes and obtaining analysed representations becomes available to children for executing literacy-related tasks.

There is growing evidence from developmental studies that children's awareness of morphology, assessed by off-line tasks (i.e., thinking about speaking, reading or writing), develops with age and instruction, and that it is related to the use of morphological representation in spelling. Nunes and Bryant (Nunes, Bryant, \& Bindman, 1997a, 1997b; Nunes, Bryant, \& Olsson, 2003) were the first to provide clear evidence for a causal connection between awareness of morphology and 
spelling, through a combination of longitudinal and intervention studies. Nunes et al. (1997a, 1997b) showed in a longitudinal study that the use of morphological markers in spelling is predicted by performance in morphological awareness tasks administered more than 1 year earlier and after controlling for the effects of age and IQ. Nunes et al. (2003) further showed that training in morphological awareness improves children's spelling of words that represent morphology and flout lettersound rules (such as "magician"). A strategy useful for spelling of the last consonant in the stem of "magician" would be to identify its stem, "magic". But there is no direct evidence from on-line spelling tasks to show that increasing the likelihood of access to the stem "magic" results in more frequent use of the "c" in the spelling of "magician".

In the remaining of this introduction the development of the understanding of the connection between words with the same stem is analysed. The question examined here is whether this is an early development and how this acquisition relates to other measures of morphological awareness. The aim of the review is to assess whether it is likely that primary school children represent words analysed into morphemes in their mental lexicon so that they can use this representation to improve the spelling of schwa vowels under priming conditions.

Evidence regarding developmental trends in the understanding of the connection between words that share the same stem was first provided by Carlisle (1988). Children in grades 4, 6 and 8 (no chronological ages are reported) were asked to supply the derived word in sentences where the base word was provided or, alternatively, to supply the base word when a derived word was provided. These tasks were performed either orally or in writing. Carlisle assessed four types of morphological transformations, which were hypothesised to represent increasing degrees of difficulty. In the first type there was no phonological or orthographic change between the base and derived form (e.g., enjoy-enjoyment) when a suffix was added. In the second, there was an orthographic change in the stem but no phonological change (e.g., rely-reliable). In the third, there was a phonological change but no orthographic change in the stem (e.g., magic-magician). Finally, pairs of words with both phonological and orthographic changes in the stem were considered (e.g., deep-depth). In both the oral and in the spelling tasks, success increased markedly from grade 4th to 8 th. For all grade levels, success in tasks that involved fewer changes in the stem was greater than in tasks that involved more changes; phonological changes affected performance more than changes in spelling only. Performance on tasks that required the children to supply the base form was superior to performance on tasks where the children supplied the derived form. At all grade levels, children were better at generating forms orally than at spelling them. Carlisle concluded that the understanding of stem morphology shows significant development from 4th to 8th grade. She hypothesised that direct, explicit instruction on morphological relations might be necessary to enhance children's understanding of language structure and spelling processes.

Leong (2000) examined how effective Canadian children in grades 4, 5, and 6 (9to 12-year-olds) were at naming the base form when the derived word was provided first, and conversely naming the derived form when the base was presented first. The stimuli contained the same morphological transformations as in Carlisle (1988). He 
found that significant progress occurred from grades 4 to 6 and that naming base forms was easier than naming derived forms. He also suggested that there might be a need for systematic and explicit instruction on word morphology in schools.

Nunes, Bryant, and Bindman (2006) examined the difficulty of preserving the spelling of stems across pairs of stimuli and analysed the connection between consistency in stem spelling and awareness of morphology. They worked with English children from grades 2 to 4 (ages 7-10). The children spelled pairs of stimuli that contained the same stems. The stimuli were pairs of words (e.g., knowknowledge) or a pair formed with a word and a pseudoword (e.g., knotknotosaurus). The pseudowords were names of dinosaurs based on a real word; the children were presented with pictures of the dinosaurs that made the connection between the dinosaur name and the real word clear ("knotosaurus" had a knot in the neck; "halfosaurus" was missing the hind half). One stimulus from each pair was spelled on one day, the second on another day. All the stems contained spellings not completely predictable from phonology (e.g., in "half" the "l" does not affect the vowel pronunciation in the usual form; in "know" and "knot" there is a silent initial "k"). Some stems changed in pronunciation across the two forms- "know" and "knowledge"-whereas others did not— "naughty" and "naughtiness". The stem was always phonologically identical in the word-pseudoword pairs. The children's spelling was scored for consistency in the spelling of the stems, not for accuracy. For the younger group the mean score for word pairs (out of 10) was 4.1; for the older group, 5.8. Thus even the children in grade 4 (age range 9-10 years) were not close to ceiling in preserving the spelling of the stem across word pairs. The means were higher for pseudoword pairs: they were (out of 10) 6 for the younger children and 8.1 for the older children. Two factors might account for this difference: first, there were no phonological changes between the base form and the dinosaur names; second, it is possible that the morphological structure of the pseudowords is more salient than that of words, because pseudowords do not have their own lexical entry in the child's vocabulary. When they are encountered, they are analysed for the first time, and this might make their morphological structure salient. These results indicated that consistency in the spelling of stems is not an all-or-nothing acquisition: there is some evidence of consistency in younger children and also a significant improvement with age.

The children's awareness of morphology was assessed through sentence analogy and word analogy tasks (see Nunes et al. 1997a). The consistency in spelling stems was related to the children's performance in the morphological awareness tasks even after partialling out the effects of age and IQ. The scores for words whose stems had different pronunciations and those which had the same pronunciation were not reported separately; thus the level of consistency may be partially explained by the phonological similarity in some pairs of stimuli. Further research should seek information on consistency in spelling stems where the pronunciation changes across the elements in the pair.

Aidinis (1998; Bryant, Nunes, \& Aidinis, 1999) replicated this progressive acquisition of consistency in spelling stems in a cross-sectional study with Greek children aged 7-10 years (grades 2-4). He also analysed the connection between awareness of morphology and consistency in spelling stems, using the same 
technique of words and pseudowords containing a real stem. The stems contained sounds for which at least two acceptable phonological representations exist; the correct representation is dependent on morphology. There were no changes in the stem phonology across related stimuli. The children in the age range 7-8 years scored significantly lower in the assessment of consistency in the spelling of stems than the 9- and 10-year-olds. Consistency in spelling stems was significantly correlated to morphological awareness (measured through sentence analogy, word analogy and productive morphology tasks) even after partialling out the effects of age and verbal ability. Thus the improvement in consistency in spelling stems and its connection to morphological awareness was replicated in another language, Greek, which is more transparent in terms of grapheme-phoneme correspondences than English, but where morphology nevertheless plays a role in spelling.

In summary: (a) when a stem is pronounced differently in the base and derived forms, children in the age range 7-8 years may not realise that the words have the same stem; (b) the acquisition of consistency in the spelling of stems is not completed in the first 4 years of primary school (by the age of 10); and (c) consistency in spelling stems is specifically related to children's morphological awareness, measured in off-line tasks.

So far no direct evidence regarding a possible facilitatory effect of priming on stem spelling has been found, but these results suggest that children in the middle years of primary school are likely to have not only whole word representation in their mental lexicon but also a representation analysed into stems and affixes. In contrast, it is possible that this analytical representation is not available to children in the beginning of primary school.

Two hypotheses follow from this conclusion. First, it should be possible to document priming effects on children's spelling of schwa vowels when the base form is well-articulated, in spite of the changes in stem pronunciation from the base to the derived form. Second, this facilitatory effect of priming on stem spelling is likely to increase with age. Although performance on on-line tasks does not depend on explicit awareness of morphology during execution, the priming effect should take place if the children do represent words in their mental lexicon analysed in constituent morphemes (though they may represent words analysed phonologically) or if they are able to isolate the stem from the rest of the word, by stripping of affixes, prior to spelling (see Taft \& Zhu, 1995, for a discussion of this process). Pseudowords do not have a representation in the mental lexicon, but they can in principle be subjected to the same process of stripping off affixes, and so their spelling can be enhanced by priming effects. The ability to carry out this process would explain why children were able to spell correctly the stems of dinosaur names in the study by Nunes et al. (2006): they must have stripped the ending "osaurus" from the pseudoword "knotosaurus" in order to use the letter " $k$ " at the beginning of this dinosaur's name. This would also explain why the correct spelling of such pseudowords correlated with morphological awareness even after controlling for age and verbal IQ.

It is not possible to anticipate from these results whether auditory or written primes will be equally effective. Because auditory primes provide phonological cues sufficient for spelling the well-articulated vowel in the stem of the base form, 
they may prove sufficient for children who represent the word stem in their mental lexicon to spell the derived form correctly. However, auditory priming has been considered more fragile (see Emmorey, 1989) and thus less effective.

In order to test the hypotheses, a study was designed which included three conditions: a baseline or no-priming condition, an only-oral priming condition, and an oral-plus-written priming condition. Primes were base forms with a wellarticulated vowel, which could be represented adequately from phonology. The measure of the effect of priming was the accuracy of spelling the schwa vowel in the target stimuli, which were derived words or pseudowords. The replication of priming effects using pseudowords was important for assessing the strength of morphological priming: whereas it would be possible to spell the vowel in the derived words correctly using specific word knowledge, there is no specific word knowledge of the pseudowords. If the children are able to spell correctly the schwa vowel of a pseudoword stem under priming conditions, they must have used a word analysis strategy that allows them to strip the suffix from the stem and to realise that the two stems - that of the prime with the well articulated vowel and that of the derived form-are the same. Evidence for this strategy would support the idea that children can analyse derived forms into stem and affixes in on-line tasks. Thus the correct spelling of the schwa vowel in pseudowords provides strong evidence for children's ability to represent morphemes in the mental lexicon. The language of the study was European Portuguese. The experimenter was the first author, a native speaker of European Portuguese.

\section{Methods}

\section{Participants}

Children ( $N=805 ; 415$ boys and 390 girls) from grades 1 to 4 (age range from 6.6 to 9.3 years) attending three state supported primary schools in the greater Lisbon area participated in the study. This sample represented $44 \%$ of the children in this age range in the three schools (Total $N=1,809$ ). All the children were born in Portugal, had European Portuguese as their first language and none had been identified for sensory, cognitive or language impairments. Table 1 displays the children's mean age (and standard deviations) by grade.

First graders were assessed towards the end of the school year (during May and June) because pre-schools typically do not provide reading instruction in Portugal.

Table 1 Mean age, standard deviation and number of children in each grade level

\begin{tabular}{llll}
\hline Grade level & Mean & $S D$ & $N$ \\
\hline First & 6.6 & 0.56 & 101 \\
Second & 7.0 & 0.22 & 215 \\
Third & 8.2 & 0.49 & 207 \\
Fourth & 9.3 & 0.63 & 282 \\
\hline
\end{tabular}


The data from 2nd, 3rd and 4th graders were collected in the first school term (during November and December). The intake of the schools reflects a high variability in children's background as described by parents' education and employment.

\section{Design}

Pairs of base (primes) and derived (target) words (24) and pseudowords (24) were constructed, with primes always containing a stressed well-articulated vowel in the stem whereas the target stimuli either contained non-stressed, schwa vowels in the corresponding position. All derived words were formed by a real stem and a derivational suffix familiar to native Portuguese speakers. These are used to form verbs ("-ilar"), nouns ("-ante”, “-aça”, “-ção") and adjectives ("-ático”). For each word-word pair, a word-pseudoword pair was created by combining a non-existing stem with the same suffix used in the word-word pairs. Base and derived word pairs were chosen from low-frequency words, with a frequency of four or less in a corpus developed by the first researcher. This corpus is based on frequency counts from printed words in school reading books used in the teaching of reading and spelling in Portuguese primary schools, from 1st to 4th grade. From 85,310 words (token) of text and application exercises entered for frequency analyses, 7,816 different words (type) emerged. This preparatory work was necessary because no frequency counts existed for European Portuguese suitable to the study of spelling in children. Lowfrequency words were chosen because previous studies have shown that highfrequency primes are less effective (Bowers, 2000; Giraudo \& Graigner, 2000).

In order to increase variability in scores and the possibility of generalising across stimuli, three types of stimulus-pairs were included in the task.

In the first type of stimulus pair, the base form contains a well-articulated vowel, open or closed, represented in writing by the letter "o". The spelling is the same in the derived form but in fluent speech the vowel is replaced with a poorly articulated schwa vowel or the semivowel /w/. An example of a base form with an open vowel in the stem and a schwa vowel in the derived form is the pair of words "negócionegociante" (business-businessperson); in the pair "tambor-tamborilar" (drum-to drum) the stem in the base form contains a closed vowel.

In the second type of stimulus pair, the base form contains a well-articulated vowel, open or closed, represented in writing by the letter "e", which is replaced in the pronunciation of the derived form by the semivowel $/ \mathrm{j} /$ - as in the pair "ceiacear" (dinner-to dine). It must be noted that in the Lisboan dialect the vowel in the base form can sound as a closed [a], (similar to the English vowel in "but"). A preliminary analysis will be carried out to investigate the possibility of confounding of the results by the use of the letter "a" in the spelling of these stimuli.

In the third type of stimulus pair, the well-articulated vowel in the stem is represented by the letter " $\mathrm{e}$ "; in fluent speech, the vowel is omitted in the derived form-as in the pair "martelo-martelar" (hammer-to hammer), resulting in a consonant cluster, pronounced as $/ \mathrm{tl} /$. 
In all the pairs, in spite of the phonological changes, the stem vowel is preserved in the spelling of the derived word.

Parallel pairs were created for the pseudo-words. The pseudo-words were formed by keeping the vowels and syllable structure of words unchanged and replacing some consonants.

Three Levels of Morphological Priming (no priming; only-oral priming; oralplus-written priming) were used for word-word and pseudoword-pseudoword pairs.

It was decided that a between-participants design would be more appropriate for this study than a within-participants design for two reasons. First, the number of words to be spelled might prove taxing for the younger children if a withinparticipants design were used: they would be required to spell six times as many stimuli (a total of 144). So, in order to use a within-participants design it would be necessary to reduce the number of items in each cell and the measure would have been less reliable. Second, within-participants designs have the disadvantage of introducing the confounding of order effects, which would be undesirable. Thus a between-participants design was adopted.

Each child spelled 24 stimuli, which was not too taxing an assignment even for the younger children. Whole classes at each grade level were randomly assigned to a cell with the restriction that each cell received a class before any cell could receive a second one; a total of 51 classes participated in the study.

Table 2 gives an overview of the design and an example of the materials for each condition.

Table 2 Design of the study

\begin{tabular}{|c|c|c|c|}
\hline & \multicolumn{3}{|c|}{ Level of morphological priming } \\
\hline & No-priming $(N=279)$ & $\begin{array}{l}\text { Only-oral priming } \\
(N=267)\end{array}$ & $\begin{array}{l}\text { Oral-plus-written priming } \\
(N=262)\end{array}$ \\
\hline \multirow[t]{2}{*}{ Words } & Condition $1(n=132)$ & Condition $2(n=133)$ & Condition $3(\mathrm{n}=131)$ \\
\hline & $\begin{array}{l}24 \text { target words presented } \\
\text { in oral sentences that } \\
\text { do not contain a prime, } \\
\text { e.g.: "Ele está a tocar / } \\
\text { pandeireta/; ele está a / } \\
\text { tamborilar/" }\end{array}$ & $\begin{array}{l}24 \text { target words presented } \\
\text { in oral sentences that } \\
\text { contain the prime, e.g.: } \\
\text { "Ele está a tocar / } \\
\text { tambor/; ele está a / } \\
\text { tamborilar/" }\end{array}$ & $\begin{array}{l}24 \text { target words presented } \\
\text { in oral and written } \\
\text { sentences that contain } \\
\text { the prime, e.g.: "Ele } \\
\text { está a tocar /tambor/; } \\
\text { ele está a /tamborilar/" }\end{array}$ \\
\hline \multirow[t]{2}{*}{ Pseudo-words } & Condition $4(n=147)$ & Condition $5(n=131)$ & Condition $6(n=131)$ \\
\hline & $\begin{array}{l}24 \text { target pseudowords } \\
\text { presented in oral } \\
\text { sentences that do not } \\
\text { contain the prime, e.g.: } \\
\text { "Ele está a tocar / } \\
\text { pandeireta/; ele está a / } \\
\text { candorilar/" }\end{array}$ & $\begin{array}{l}24 \text { target pseudowords } \\
\text { presented in oral } \\
\text { sentences that contain } \\
\text { the prime, e.g.: "Ele } \\
\text { está a fazer /candor/; } \\
\text { ele está a /candorilar/" }\end{array}$ & $\begin{array}{l}24 \text { pseudowords } \\
\text { presented in oral and } \\
\text { written sentences that } \\
\text { contain the } \\
\text { pseudoword stem, e.g.: } \\
\text { "Ele está a fazer / } \\
\text { candor/; ele está a / } \\
\text { candorilar/" }\end{array}$ \\
\hline
\end{tabular}

Note: In each sentence, the primes and targets are indicated within forward slashes; primes come first, targets follow

In the no-priming conditions, primes are morphologically unrelated to the targets; in the remaining conditions, primes are morphologically related to the targets because they share the same stem 


\section{Procedure}

The spelling task was administered in the classroom by the first author, a native speaker of European Portuguese; the class teacher was also present in the classroom and was asked not to provide information on any of the spellings. The children worked individually; care was taken to avoid copying. The target words and pseudowords were presented in the context of sentences (see Appendix 1). The same sentence was used for words and pseudowords, thereby controlling for some task elements (e.g., sentence context and word class). Order of stimuli was randomised for preparation of the final list; the same order of stimuli was used across conditions.

Children in the no-priming (or baseline) condition (cells 1 and 4 in Table 2) and in the only-oral priming condition (cells 2 and 5) were provided with an answer sheet consisting of a table with numbered rows. Children in the oral-plus-written priming condition (cells 3 and 6) received an answer sheet with numbered rows; each number was followed by the sentence used during task presentation. In each sentence, a blank space indicated where the target word was to be written by the children.

In the no-priming condition the sentence contained an irrelevant word (cell 1) or pseudo-word (cell 4), replacing the item that was used as prime for the priming conditions. Minor adjustments in the sentences were sometimes required (e.g. the change of gender to match the irrelevant word: for example, the word "tábua" (board) is feminine and was used to replace "martelo" (hammer), which is masculine, so the article was changed correspondingly). Primes were not emphasised in any way. The sentences were presented in a typically fluent and colloquial speech register. Appendix 1 presents the list of sentences; the target stimuli (presented orally to all children) are underlined here to help identify the items. The use of sentences in all conditions allowed for the use of the same instructions in all conditions. Table 3 presents a full example of how the first sentence fits with this procedure.

The following oral instructions were given in the no-priming and only-oral priming conditions: "I am going to say a sentence. Then I will repeat a word from the sentence. I would like you to write down this word that I say again after the sentence. Let's start with number 1". In the oral-plus-written priming condition, the only difference was: "I am going to say a sentence that is written on your answer sheet"; then, the remainder of the instruction was provided.

The sentence was read, the target word or pseudo-word was repeated, and the children wrote it down. The next sentence was only presented after ensuring that all the children had completed the item.

The method was the same for the children who spelled pseudo-words. The only difference is that they were told that they were going to spell words invented by the experimenter and that they should write them in the way they thought was right.

\section{Results}

Words and pseudo-words were scored only for the correctness of the vowel used in the stem of the target derived form-i.e., the children were given one point for using 
Table 3 Examples of presentation of sentence 1 by spelling condition:

Spelling Condition 1-No-priming/Words:

The experimenter said:

"Ele está a tocar pandeireta; está a tamborilar". Tamborilar.

The children's answer sheet had a number corresponding to the sentence. The children were asked to write the target word, which they heard twice, next to the sentence number.

Spelling Condition 2-Only-oral Priming/Words:

The experimenter said:

"Ele está a tocar tambor; está a tamborilar". Tamborilar.

The children's answer sheet had a number corresponding to the sentence. The children were asked to write the target word, which they heard twice, next to the sentence number.

Spelling Condition 3-Oral-plus-written Priming/Words:

The experimenter said:

"Ele está a tocar tambor; está a tamborilar". Tamborilar.

The children's answer sheet read:

Ele está a tocar tambor; está a

The children were asked to write the target word, which they heard twice, above the line.

Spelling Condition 4-No-priming/Pseudo-words:

The experimenter said:

"Ele está a tocar pandeireta; está a candorilar".Candorilar.

The children's answer sheet had a number corresponding to the sentence. The children were asked to write the invented word, which they heard twice, next to the sentence number.

Spelling Condition 5-Only-oral Priming/Pseudo-words:

The experimenter said:

"Ele está a fazer candor; está a candorilar". Candorilar.

The children's answer sheet had a number corresponding to the sentence. The children were asked to write the invented word, which they heard twice, next to the sentence number.

Spelling Condition 6-Oral-plus-written Priming/Pseudo-words:

The experimenter said:

"Ele está a fazer candor; está a candorilar". Candorilar.

The answer sheet read:

Ele está a fazer candor; está a

The children were asked to write the invented word, which they heard twice, above the line.

the vowels "o" and "e" in the appropriate derived words. For pseudowords, the vowel was considered correct if it was the same vowel- "o" or "e" - that was used to spell the base form. When this scoring is applied to the non-primed condition, it provides baseline information on correct use of the vowel in the derived form. Other parts of the words and pseudo-words were not considered in scoring (e.g. a hierarchical position rule determines whether the nasal vowel in "tamborilar" is marked with "m" or " $n$ "; this variation in spelling was not considered in the scoring, which referred only to whether the correct vowel was used).

Because this spelling task was not used previously, it was necessary to carry out preliminary analyses on task reliability and normality of the distribution. The Cronbach's alpha for item analysis showed that the task was highly consistent 
(Cronbach's $\alpha=.82$ ). The analysis of Skewness showed that the scores were not significantly skewed (Skewness $=0.147$; Standard Error of Skewness $=0.086$; $z=1.70, p<0.05)$. Thus the assumption of normality was accepted and parametric statistics will be used in the test of the hypotheses.

Our hypotheses led to the predictions that follows.

(1) Older children's spelling of the schwa vowels in words will improve significantly with priming; this effect may not be observed in the younger children, whose mental lexicon may not contain a separate representation for the stems and affixes. Thus a significant interaction between priming condition and grade level is predicted; consequently, the main effect of priming may or may not be significant.

(2) The same prediction is made for pseudowords: a significant interaction between priming and grade level is expected. If children are able to strip the suffix from the derived pseudoword and identify its stem, they should benefit from priming. However, because young children may be less able (or unable) to do this, they would benefit less from priming than the older children.

(3) Only-oral priming is not expected to be as effective as oral-plus-written priming due to the fragility of oral primes. Thus only-oral priming might either show beneficial effects later than oral-plus-written priming or might not be effective with pseudowords because the children would have to perform the word analysis for the first time during this on-line task. The mere lack of familiarity of pseudowords may render the task more difficult and the more fragile oral priming ineffective.

These predictions will be tested through separate analyses of variance, the first with the spelling of the schwa vowel in words as the dependent variable and the second with the spelling of the schwa vowels in pseudowords as the dependent variable. An overall analysis of variance, including words and pseudo-words, was not used because it would produce unnecessary comparisons and interaction terms.

Separate analyses by participants and by items were computed in order to assess the stability of the findings. Because the number of participants differs across cells, the analysis by items must be applied to the proportion of correct responses. The proportion correct in each cell is necessarily the same whether the calculation is by participants or by items. In order to reduce the number of tables, we present here the proportion correct.

Table 4 displays the summary data for these analyses, with the proportion correct and standard deviations for correct of vowel spelling by Level of Morphological Priming and Grade for words and pseudowords.

Some trends are suggested by these proportions. First, in the baseline (nopriming) condition, there is an improvement with grade in the spelling of the target vowels for words but not for pseudowords. The proportion correct for words does not reach ceiling at grade 4: $61 \%$ correct in the no-priming condition. This level of performance leaves room for improvement under priming conditions. Second, the proportion correct of words and pseudo-words spelled with the correct vowel across priming conditions increases in grades 3 and 4; there does not appear to be an improvement in the earlier grades with priming. Children in 1st grade actually 
Table 4 Means and standard deviations (in brackets) for the proportion of correct spelling of vowels, by level of morphological priming, type of stimulus and grade

\begin{tabular}{llllll}
\hline Type of stimulus & \multicolumn{2}{l}{ Grade } & \multicolumn{3}{l}{ Level of morphological priming } \\
\cline { 3 - 6 } & & & No-priming & Only-oral priming & Oral-plus-written priming \\
\hline Words & 1 & $M(S D)$ & $.43(.13)$ & $.46(.12)$ & $.46(.17)$ \\
& 2 & $M(S D)$ & $.51(.12)$ & $.50(.12)$ & $.48(.16)$ \\
& 3 & $M(S D)$ & $.53(.20)$ & $.62(.16)$ & $.66(.15)$ \\
Pseudo-words & 4 & $M(S D)$ & $.61(.16)$ & $.68(.19)$ & $.72(.14)$ \\
& $\mathrm{T}$ & $M(S D)$ & $.54(.17)$ & $.58(.18)$ & $.60(.19)$ \\
& 1 & $M(S D)$ & $.45(.13)$ & $.37(.15)$ & $.43(.09)$ \\
& 2 & $M(S D)$ & $.44(.16)$ & $.45(.13)$ & $.48(.14)$ \\
& 3 & $M(S D)$ & $.43(.11)$ & $.43(.14)$ & $.61(.15)$ \\
& 4 & $M(S D)$ & $.40(.12)$ & $.55(.15)$ & $.67(.16)$ \\
& $\mathrm{T}$ & $M(S D)$ & $.42(.13)$ & $.47(.16)$ & $.59(.17)$
\end{tabular}

showed poorer performance when spelling pseudowords under priming conditions than when spelling pseudowords under no-priming condition, though this difference is not likely to be significant.

Preliminary analyses showed that there were no significant differences as a function of School (three different schools participated) or Gender. These variables were removed from further analyses.

Preliminary analyses also showed that the same pattern of results was obtained with separate analyses for each of the three types of stimuli (8 instances of each type). In order to investigate the possibility of confounding of the results by the use of the letter "a" in the second type of stimulus (please see the design section), a preliminary analysis considered the percentage of target words written with "a". Only four children ever used the vowel "a" for these target words or pseudo-words, corresponding to $0.3 \%$ of all the spellings for this stimulus type. The vowel "a" was observed in $1 \%$ of the spellings of "baleal" and $0.5 \%$ of the spellings of "manusear" under the only-oral priming condition; under the oral-plus-written priming condition, $0.5 \%$ of the spellings of "recear" and $0.5 \%$ of the spellings of "tear" contained the letter "a". These percentages were considered too small to influence the data analysis and the possibility of a negative influence of a Lisboan dialect on the children's spelling can therefore be disregarded.

The reliability and normality of distributions were poorer when each of the types of stimulus pairs was analysed separately. This was expected because the number of items was smaller for each type than for the total, and reliability increases when a larger number of intercorrelated items is used. Because the reliability of the task was good when the items were considered together, it was decided to analyse all items together. 
Priming effects on words

In order to assess the effects of priming on the correct spelling of the vowels in words, a between-participants analysis of variance was performed with two main effects: Level of Morphological Priming (3: no-priming; only-oral priming; oralplus-written priming); and Grade (4: 1 st to 4 th grade). The dependent variable was the proportion of correctly spelled vowels. The main effect of Priming was not significant $\left(F_{(2,384)}=2.46, p=0.160\right)$; the main effect of Grade was significant $\left(F_{(3,384)}=17.82, p<0.005\right)$ and the interaction between Priming and Grade was also significant $\left(F_{(6,384)}=2.14, p<0.05\right)$. Thus the predicted interaction between priming and grade was observed. Figure 1 depicts the interaction between priming and grade for the spelling of words.

Post-hoc tests using the Bonferroni adjustment showed that accuracy in the spelling of vowels was significantly lower in the no-priming and only-oral priming conditions than in the oral-plus-written priming condition $(p<.001)$; the only-oral priming condition did not differ significantly from the no-priming condition $(p=0.10)$. Pair-wise comparisons (using the criterion of $p<0.05$ ) showed that significant differences were observed between the oral-plus-written priming and the no-priming condition for children in grades $3(p<0.005)$ and $4(p=0.005)$. Comparisons between grade levels showed that the performance of children in grades 3 and 4 was significantly better than that of the children in grades 1 $(p<.001)$ and $2(p<.001)$; children in grade 4 also performed significantly better than children in grade $3(p<.001)$; the performance of children in grades 1 and 2 did not differ $(p=0.54)$.

The analysis of variance was repeated using a by-items analysis. In this case, the proportions of corrects vowel spellings are the same in each cell as in the byparticipants analysis, but the variance refers to differences between items rather than

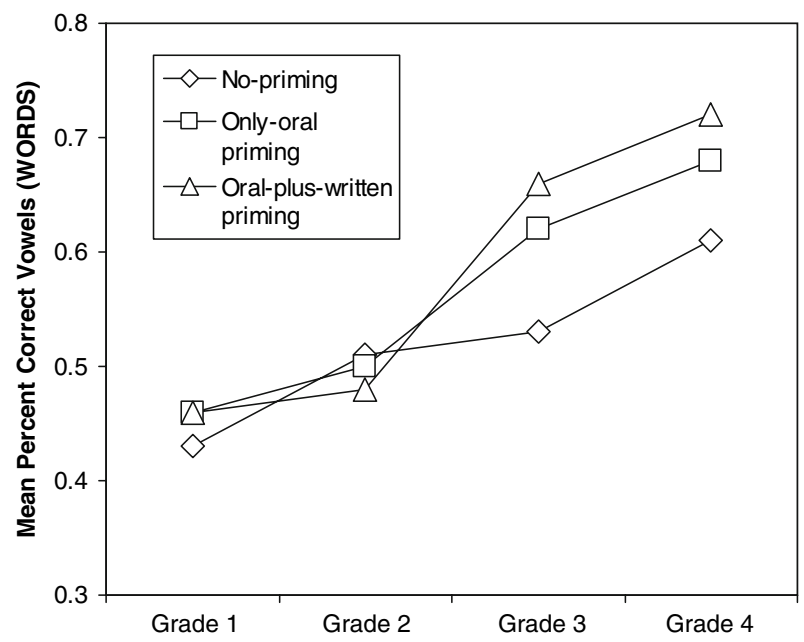

Fig. 1 Effects of priming in the proportion of correct spelling of vowels in words, by grade 
between participants. The main terms are Priming Condition (3: no-priming, onlyoral priming, and oral-plus-written priming) and Grade (4: 1st, 2nd, 3rd and 4th). The analysis by items revealed significant effects of Priming Condition $\left(F 2_{(1}\right.$, 23) $=17.03, p<0.001)$ and $\operatorname{Grade}\left(F 2_{(1,23)}=103.50, p<0.001\right)$, and a significant interaction between Priming Conditions and Grade $\left(F 2_{(1,23)}=12.56, p<0.005\right)$. Pairwise comparisons (at 0.05 level) with Bonferroni adjustment revealed that items spelled in the no-priming condition were spelled significantly less correctly than items in the only-oral priming and in the oral-plus-written priming conditions. No significant difference was found between only-oral priming and oral-plus-written priming $(p=0.40)$. Correct spelling of items did not differ between grades 1 and 2 $(p=0.15)$, and was significantly lower than in grades $3(p<0.001)$ and 4 $(p<0.001)$.

In conclusion, the spelling of schwa vowels in derived words without priming with a morphologically related stem improves through grades but is not at ceiling in grade 4 . The improvement in correct spelling of the schwa vowel in words under priming condition supports the hypothesis that priming is effective for children in the middle grades of primary school but not for the young ones. Only-oral primes did prove weaker than oral-plus-written primes, confirming their greater fragility.

Priming effects on pseudo-words

A between-participants analysis of variance with correct spelling of the schwa vowel in pseudowords as the dependent variable was performed. The main factors were Priming Conditions (3 levels) and Grade (4 levels).

The results replicated those observed when the dependent measure was vowel spelling in words. The main effect of priming in the analysis by participants was not significant $\left(F_{(2,397)}=2.97, p=0.13\right)$ and the interaction between Priming Condition and Grade was significant $\left(F_{(6,397)}=8.48, p<0.001\right)$. The Grade effect was not significant in the case of pseudo-word vowel spelling $\left(F_{(2}\right.$, 397) $=1.35, p=0.35$ ).

Further analyses were performed using the Bonferroni adjustment. These analyses replicate the results of the previous one: the oral-plus-written priming condition differed significantly from the baseline condition $(p<0.001)$ but onlyoral priming did not $(p=0.70)$. Pair-wise comparisons (at .05 level) showed that children in grades 3 and 4 performed significantly better in the oral-plus-written priming than in both the baseline and the only-oral priming condition. Only children in grade 4 performed significantly better in the only-oral priming than in the baseline condition $(p<0.001)$.

The analyses by items with pseudo-words showed that there were significant effects of Priming Condition $\left.\left(F 2_{(1,} 23\right)=23.69, \quad p<0.001\right)$, Grade $\left(F 2_{(1}\right.$, 23) $=28.75, p<0.001)$, and a significant interaction between Priming Condition and Grade $\left(F 22_{(1,23)}=37.31, p<0.001\right)$. Pairwise comparisons $(p<0.05)$ revealed that accuracy in the no-priming condition did not differ significantly from the only-oral priming condition $(p=0.55)$. The spelling of items in the oral-pluswritten priming condition was significantly more correct than in the no-priming 
$(p<0.001)$ and only-oral priming $(p=0.001)$ conditions. There were no differences in accuracy of spelling the vowels between grades 1 and $2(p=1.00)$. Items spelled in grade 3 were significantly better spelled than in grades $1(p<0.05)$ and 2 $(p<0.05)$. Items spelled in grade 4 were also significantly better spelled than in grades $1(p<0.001), 2(p<0.001)$ and $3(p<0.05)$.

Thus the results for the spelling of schwa vowels in pseudowords confirm those observed with words, showing that the observed trends are robust.

\section{Conclusions and discussion}

We conclude that both analyses support the prediction that morphological priming is effective in improving the spelling of schwa vowels in the stem of derived forms for children in the middle grades of primary school but not for younger children. The results are consistent with the hypothesis that young children do not have a morphologically analysed representation of words in their mental lexicon. Therefore they cannot use a morphologically related prime to facilitate the spelling of schwa vowels in words, even if the prime has a clearly pronounced vowel and is presented in writing.

These results are to some extent surprising. Why should young spellers not use the information that is in front of them to spell words that they may not be able to spell? The answer must be that they cannot see the relevance of the information: all the stems used in this study had a change in pronunciation from the base form to the derived form so they could not see the connection between the two forms. Thus when producing the spelling of the derived forms, they searched for phonological or whole-word representations, but not for morphologically related representations.

Their level of success on these vowels was slightly less than $50 \%$ correct. If we consider that the sounds that they were spelling, /w/ and / $/ \mathrm{j}$, have two possible representations in Portuguese, "o" or "u" and "e" or "i", respectively, this level of accuracy suggests that their performance is at chance level. If their spelling strategies were based on letter-sound correspondences, they would be systematically choosing the incorrect vowel; a correct vowel choice would only be possible if they were using morphological spelling strategies. Because the words used in the study were low frequency words, their possibility of using whole word representation was also low. This explains why there was no substantial difference between the spelling of words and pseudowords for the youngest children, in grade 1.

Oral-plus-written primes were effective for the children in the middle grades. Thus they realised the relevance of the information provided to them and used this information in spelling.

Only-oral primes proved effective both for children in grades 3 and 4 in the spelling of words. Children in grade 3 did not benefit from only-oral priming in the spelling of pseudowords whereas those in grade 4 did. This difference suggests that the older group was able not only to recognise the relevance of the morphologically related primes but also to carry out on-line morphological analyses of the pseudowords. Because, as suggested by Emmorey (1989), oral primes are fragile, greater facility with morphological analysis might be required for children to benefit 
from only-oral primes in spelling. This use of implicit information was independent of meaning associations previously developed between words since it was manifested in the spelling of pseudowords.

Priming was effective despite the fact that primes were presented in a sentence context, thus separated by a set of intervening items from their targets. There is evidence from studies with adults that strong priming effects can still be found even when primes and targets sharing the same morpheme are separated by up to 50 intervening items (Stoltz \& Feldman, 1995). Campbell also found evidence of orthographic priming effects when the primes and targets were separated. Her studies used pseudo-word spelling under dictation but did not use morphological priming: she analysed the effects of orthographic priming, when equally acceptable representations can be used for the same sounds. She showed robust effects both with adults (1983) and children (1985), but the effects with children were weaker. In this study, the sentence context was used to make the tasks more meaningful and more interesting for the children. However, sentence noise may compete with the fragile orally presented primes, to use Emmorey's (1989) term, and may have reduced its effect. It is possible that only-oral primes would have been more effective without the sentence context.

Priming was effective in the absence of any explicit suggestion to the children that they could use a clue from the sentences they heard in order to help them with their spelling. Further research could investigate whether the improvement in the spelling of schwa vowels would be more marked if explicit directions to look for a clue were used. Carlisle (1988) did suggest that children may require explicit morphological training in order to be able to make better use of morphological connections in spelling. Although this study showed that such explicit instruction is not necessary for children in the middle grades, it is quite possible that it would be beneficial for them and perhaps even more so for the children in the early grades.

This raises interesting educational implications. In Portuguese primary schools, the teaching of spelling typically treats morphological representation as instances to be memorised, as if these were simply exceptions to phonological representation. Some teachers explicitly indicate to their pupils that the sound $/ \mathrm{w} /$ is often represented by the letter "o", without any reference to the contexts in which this occurs (which is always in unstressed syllables). Children are asked to practice spelling lists through copying and are tested through single-word dictation. When the teachers dictate the words, they often do not use the colloquial pattern of the language, but over-correct their pronunciation to provide the phonological information required for correct spelling. This teaching approach does not encourage the identification of morphological representations in writing. The present study shows that, at least in grades 3 and 4, children are capable of using morphological representations in spelling. So it would be appropriate to try to conceive teaching methods that draw on the children's ability, and perhaps place less emphasis on the acquisition of word-specific knowledge, which is basis of the current approach.

We believe that this study showed that children in the middle grades in primary school use morphological information in on-line spelling tasks. It could be argued that the priming effects observed in the oral-plus-written condition resulted from 
either morphological similarity, or orthographic similarity or both. However, the only-oral priming condition was effective in improving vowel spelling for children in grade 4; in this condition, it was not possible to explain the results by orthographic similarity. Further studies could add a priming condition where primes are orthographically similar but morphologically unrelated (and primes are presented in writing). This is possible in English, where words as "harm", "harmony" and "harmless" could be used but, in Portuguese, it is difficult to find primes that are morphologically unrelated to the targets with a comparable level of orthographic similarity in the stems.

To conclude, this study provides new evidence that morphological priming can be used successfully to enhance the spelling of schwa vowels, which causes difficulties for Portuguese children up to the middle grades in primary school. The study has significant implications for educational practice, which should be put to the test through further research. Morphological priming could be a tool to help children consider unexplored spelling strategies and build a new framework for thinking about spelling, which can be productively used for further learning.

\section{Appendix 1: Sentences in the spelling task by type of stimulus pair}

Notes: The numbers on the left of the sentence indicate the order of the stimulus in the list. The same sentences were used in all conditions; in the no-priming condition the related stem was replaced by an unrelated word or expression, which appears in brackets. The target stimuli are underlined here but were not written on the children's papers because they were dictated. The pseudo-word pair appears at the end of the sentence; they replace the corresponding expressions in the sentence.

Type 1: Well-articulated vowel spelled as "o" in the base form; schwa vowel pronounced as $/ \mathrm{w} /$ in the target stimulus

1- Ele está a tocar tambor (pandeireta); ele está a tamborilar. (fazer candorcandorilar)

5- És um grande maroto (malandro); só fazes marotices. (ranoto-ranotices)

7- Que bom aroma (cheirinho); este café é mesmo aromático. (biromabiromático)

12- Fiz um bom negócio (venda); não há melhor negociante do que eu. (gabóciogabociante)

9- O teu amigo é um grande cabriola (atrevido); anda sempre a cabriolar. (bacriola-bacriolar)

16- Estou ao seu dispor (se precisar de mim); estou à sua disposição. (pistorpistorição)

18- Estás sempre no gozo (brincadeira); isso é que é gozar. (abogo-abogar)

21- Ele ganhou o concurso do maior bigode (barba); que grande bigodaça que ele tinha. (gabode-gabodaça) 
Type 2. Well-articulated vowel spelled as "e" in the base form; schwa vowel pronounced as $/ \mathrm{j} /$ in the target stimulus

3- São horas da ceia (de comer); vamos todos cear. (badeia-badear)

8- Os pássaros chilreiam (saltam); estão a chilrear no telhado. (chulbeiamchulbear)

10- Na minha terra caçavam-se baleias (a minha terra chama-se); por isso se chama Baleal. (golneias-Golneal)

13- Eu saboreio (gosto de) o gelado; estou a saborear o gelado. (namuteionamutear)

15- Eu manuseio o martelo; (estou a) manusear. (namuteio-namutear)

17- Eu penteio (trato) do cabelo; estou a pentear o cabelo. (banzeio-banzear)

20- Não tenhas receio (medo) do cão; não há nada a recear. (reveio-revear)

23- A aranha fez uma teia (estendeu os seus fios); parece mesmo um tear. (tabeia-tabear)

Type 3. Well-articulated vowel spelled as "e" in the base form; vowel's pronunciation omitted in the target stimulus

2- Uso um martelo (uma tábua) para martelar. (barfelo-barfelar)

4- Um profeta (adivinho) é alguém que sabe profetizar o futuro. (trovetatrovetizar)

6- Ter inveja (repartir com os outros não) é ser invejoso. (manfeja-manfejoso)

11- O papel (lápis) é comprado na papelaria. (bramel-bramelaria)

14- Afastei a aranha com um chinelo (a aranha levou uma); levou uma chinelada. (binelo-binelada)

19- A pele (pata) do meu gato é muito peluda. (bene-benuda)

22- Comprei uma cautela (disse bom-dia) ao cauteleiro. (gaudela-gaudeleiro)

24- A coberta (colcha) da minha cama está por cima do cobertor. (ropertaropertor)

\section{References}

Aidinis, A. (1998). Phonemes, morphemes and literacy development: Evidence from Greek. Unpublished Ph.D. Thesis, Department of Child Development and Learning, University of London, Institute of Education.

Bowers, J. S. (2000). The modality-specific and -nonspecific components of long-term priming are frequency sensitive. Memory \& Cognition, 28(3), 406-414.

Bryant, P., Nunes, T., \& Aidinis, A. (1999). Different morphemes, same spelling problems: Crosslinguistic developmental studies. In M. Harris \& G. Hatano (Eds.), Learning to read and write: A cross-linguistic perspective (pp. 112-133). Cambridge: Cambridge University Press.

Campbell, R. (1983). Writing non-words to dictations. Brain and Language, 19, 153-178.

Campbell, R. (1985). When children write nonwords to dictation. Journal of Experimental Child Psychology, 40, 133-151. 
Caramazza, A., Laudanna, A., \& Romani, C. (1988). Lexical access and inflectional morphology. Cognition, 28, 297-332.

Carslisle, J. F. (1988). Knowledge of derivational morphology and spelling ability in fourth, sixth, and eighth graders. Applied Psycholinguistics, 9, 247-266.

Chialant, D., \& Caramazza, A. (1995). Where is morphology and how is it processed? In L. B. Feldman (Ed.), Morphological aspects of language processing (pp. 55-78). Hillsdale, NJ: Lawrence Erlbaum.

Emmorey, K. D. (1989). Auditory morphological priming in the lexicon. Language and Cognitive Processes, 4(2), 73-92.

Forster, K., \& Azuma, T. (2000). Masked priming for prefixed words with bound stems: Does submit prime permit? Language and Cognitive Processes, 15, 539-561.

Giraudo, H., \& Graigner, J. (2000). Effects of prime word frequency and cumulative root frequency in masked morphological priming. Language and Cognitive Processes, 15, 421-444.

Karmiloff-Smith, A. (1992). Beyond modularity: A developmental perspective on cognitive science. Cambridge, MA: MIT Press.

Kempley, S. T., \& Morton, J. (1982). The effects of priming with regularly and irregularly related words in auditory word recognition. British Journal of Psychology, 73, 441-454.

Laudanna, A., Badecker, W., \& Caramazza, A. (1989). Priming homographic stems. Journal of Memory and Language, 28, 531-546.

Laudanna, A., Badecker, W., \& Caramazza, A. (1992). Processing inflectional and derivational morphology. Journal of Memory and Language, 31, 333-348.

Laudanna, A., Cermele, A., \& Caramazza, A. (1997). Morpho-lexical representations in naming. Language and Cognitive Processes, 12, 49-66.

Leong, C. K. (2000). Rapid processing of base and derived forms of words and grades 4, 5 and 6 children's spelling. Reading and Writing: An Interdisciplinary Journal, 12, 277-302.

Nunes, T., Bryant, P., \& Bindman, M. (1997a). Morphological spelling strategies: Developmental stages and processes. Developmental Psychology, 33, 637-649.

Nunes, T., Bryant, P., \& Bindman, M. (1997b). Learning to spell regular and irregular verbs. Reading and Writing: An Interdisciplinary Journal, 9, 427-449.

Nunes, T., Bryant, P., \& Olsson, J. (2003). Learning morphological and phonological spelling rules: An intervention study. Reading and Writing: An Interdisciplinary Journal, 7, 289-307.

Nunes, T., Bryant, P., \& Bindman, M. (2006). The effects of learning to spell on children's awareness of morphology. Reading and Writing: An Interdisciplinary Journal, 19, 767-787.

Raveh, M., \& Rueckl, J. G. (2000). Equivalent effects of inflected and derived primes: Long-term morphological priming in fragment completion and lexical decision. Journal of Memory and Language, 42, 103-119.

Stolz, J., \& Feldman, L. (1995). The role of orthographic and semantic transparency of the base morpheme in morphological processing. In L. Feldman (Ed.), Morphological aspects of language processing (pp. 109-129). Hillsdale, NJ: Lawrence Erlbaum.

Taft, M., \& Zhu, X. (1995). The representation of bound morphemes in the lexicon: A Chinese study. In L. B. Feldman (Ed.), Morphological aspects of language processing (pp. 293-316). Hillsdale, NJ: Lawrence Erlbaum. 
Reproduced with permission of the copyright owner. Further reproduction prohibited without permission. 